https://doi.org/10.15407/ujpe64.2.157

A. HASHIM, ${ }^{1}$ K.H.H. AL-ATTIYAH, ${ }^{2}$ S.F. OBAID ${ }^{2}$

${ }^{1}$ University of Babylon, College of Education For Pure Sciences, Department of Physics, Iraq

(Iraq;e-mail: ahmed_taay@yahoo.com)

${ }^{2}$ University of Babylon, College of Science, Department of Physics, Iraq (Iraq)

\title{
FABRICATION OF NOVEL (BIOPOLYMER BLEND-LEAD OXIDE NANOPARTICLES) NANOCOMPOSITES: STRUCTURAL AND OPTICAL PROPERTIES FOR LOW-COST NUCLEAR RADIATION SHIELDING
}

\begin{abstract}
Low-cost polymer nanocomposites prepared for the nuclear radiation shielding have highly linear attenuation coefficients, light weight, and elastic, good mechanical, optical, and dielectric properties. The carboxymethyl cellulose $(C M C)$-polyvinyl pyrrolidone $(P V P)$ polymeric blend is prepared with concentrations: $60 \mathrm{wt} . \%$ CMC and $40 \mathrm{wt} . \%$ PVP. The lead oxide nanoparticles are added to the CMC-PVP blend with different concentrations: 0, 2, 4, 6, and $8 w t . \%$. The structural and optical properties of $\left(C M C-P V P-P b O_{2}\right)$ nanocomposites are studied. The results show that the absorbance of the $(C M C-P V P)$ blend increases and the energy band gap decreases, as the concentration of $\mathrm{PbO}_{2}$ nanoparticles increases. The optical constants of the $(C M C-P V P)$ blend increase with the concentration of lead oxide nanoparticles. The (CMC$\left.\mathrm{PVP}-\mathrm{PbO}_{2}\right)$ nanocomposites have highly linear attenuation coefficients for gamma radiation.

Keywords: nanocomposites, lead oxide, structure, absorbance, gamma radiation, attenuation.
\end{abstract}

\section{Introduction}

Nuclear medicine has grown quickly in recent years. With the invention of gamma cameras, PET \& SPECT, the use of radioisotopes in the diagnosis and treatment of diseases has become inevitable. Ionizing radiation is presented as a factor that has always produced deleterious biological effects, which can cause serious incurable damages in people who somehow deal with radiation. Although the deleterious effects usually require relatively high doses, molecular biological studies have shown that the risk of malignancy and cancer for ionizing radiation is a simple function of the dose of radiation, and the threshold is lacking. Hence, the hypothesis that low-dose radiation entails no risk of cancer has no basis [1]. Polymers are high molecular weight compounds composed of units called monomers. Numerous molecules are regularly attached to each other by chemical bonds and form polymers. Polymers are used in many areas such as building materials, adhesives, electronic

(c) A. HASHIM, K.H.H. AL-ATTIYAH, S.F. OBAID, 2019

ISSN 2071-0194. Ukr. J. Phys. 2019. Vol. 64, No. 2 tool parts, insulating materials, metal materials, insulation materials, textile and paper industries. The technologies involving radiation start to be used in a variety of different fields such as industries, nuclear power stations, particle accelerators, and medical hospitals. Thus, the radiation protection becomes important, since radiation has hazardous effects for human health. Although there are three ways for the radiation protection, the shielding of radiation is the most commonly used method. Many different studies on the linear attenuation coefficient for different materials can be found in [2]. With the increasing application of gamma radiation in industry, medicine, agriculture, nuclear reactors, and particle accelerators, the shielding becomes of a paramount importance in order to use this radiation without a risk. The probability of the interaction of gamma-rays per unit length of a given absorber characterizes its linear attenuation coefficient. However, the linear attenuation coefficient depends on the physical state of a material. For this reason, it is usually substituted by the mass attenuation coefficient, which is the linear attenuation 
coefficient divided by the density. When a gamma radiation beam reaches some absorber material, the attenuation occurs in accordance with its chemical composition and the photon energy, resulting in a reduction in its intensity. A decrease in the beam intensity results from a combination of the absorption and deflection of photons. Therefore, the mass attenuation coefficient depends on the absorber nature, as well as on the gamma-ray initial energy [3]. Polymeric composites have high strength and stiffness, low weight, and high corrosion resistance [4]. Nanocomposites on the basis of semiconductor nanoparticles and a polymer matrix are promising materials for the application in optoelectronics, for the creation of luminescent materials, sensor electronics, ..., etc. [5].

\section{Materials and Methods}

Films of the pure carboxymethyl cellulose (CMC)polyvinyl pyrrolidone (PVP) polymeric blend and carboxymethyl cellulose (CMC)-polyvinyl pyrrolidone (PVP) doped with lead oxide $\left(\mathrm{PbO}_{2}\right)$ nanoparticles have been prepared, by using the casting method. The polymer blend was prepared with 60 wt.\% CMC and 40 wt.\% PVP. The lead oxide $\left(\mathrm{PbO}_{2}\right)$ nanoparticles were added to the (CMC-PVP) blend in different concentrations: $0,2,4,6$, and 8 wt.\%. The optical properties of nanocomposites were measured by using UV/1800/Shimadzu in the wavelength interval (220-800) nm. Nanocomposites $\left(\mathrm{CMC}-\mathrm{PVP}-\mathrm{PbO}_{2}\right)$ aimed at the gamma radiation shielding have been examined, by using a source of gamma rays (Cs-137, $5 \mu \mathrm{Ci}$ ) to investigate the attenuation of gamma rays. The samples of (CMC-PVP$\mathrm{PbO}_{2}$ ) nanocomposites were arranged in front of a collimated beam emerged from a gamma ray source which was placed at a distance of $3 \mathrm{~cm}$ from the detector. The sample of (CMC-PVP- $\left.\mathrm{PbO}_{2}\right)$ nanocomposite was positioned at a distance of $1 \mathrm{~cm}$ from the gamma ray source. The gamma ray fluxes passed through the nanocomposites were measured by a Geiger-Müller counter to estimate the linear attenuation coefficients. The absorption coefficient $(\alpha)$ is defined as the ability of a nanocomposite to absorb the light of a given wavelength [6]:

$\alpha=2.303 A / t$,

where $A$ is the absorbance and $t$ is the thickness in $\mathrm{cm}$.
The non-direct transition model for amorphous semiconductors proposed in [7] reads

$\alpha h v=B\left(h v-E_{g}\right)^{r}$

where $B$ is a constant related to the properties of the valence and conduction bands, $h v$ is the photon energy, $E_{g}$ is the optical energy band gap, and $r=2$ or 3 for indirect allowed and indirect forbidden transitions. The refractive index $n$ of $\left(\mathrm{CMC}-\mathrm{PVP}-\mathrm{PbO}_{2}\right)$ nanocomposites can be calculated, by using the relation [8]

$n=\left(1+R^{1 / 2}\right) /\left(1-R^{1 / 2}\right)$.

The extinction coefficient $k$ of nanocomposites is given by the relation [8]

$K=\alpha \lambda / 4 \pi$.

The real and imaginary parts of the dielectric constant $\left(\varepsilon_{1}\right.$ and $\left.\varepsilon_{2}\right)$ of $\left(\mathrm{CMC}-\mathrm{PVP}-\mathrm{PbO}_{2}\right)$ nanocomposites can be calculated by the relations [9]

$\varepsilon_{1}=n^{2}-k^{2}$,

$\varepsilon_{2}=2 n k$.

The optical conductivity $\left(\sigma_{o p}\right)$ can be written as [9]

$\sigma_{o p}=\frac{\alpha n c}{4 \pi}$.

The photon attenuation coefficients have been evaluated, by comparing $N$ and $N_{0}$, which are the measured counting rates in a detector, respectively, with and without the absorber $x \mathrm{~cm}$ in thickness [2]:

$N=N_{0} \mathrm{e}^{-\mu x}$

\section{Results and Discussion}

Figure 1 shows the variation of the optical absorbance spectra of $\left(\mathrm{CMC}-\mathrm{PVP}-\mathrm{PbO}_{2}\right)$ nanocomposites with the photon wavelength for different concentrations of lead oxide nanoparticles. The (CMC-PVP) blend has the very limited UV absorbance, which is enhanced with the addition of lead oxide $\left(\mathrm{PbO}_{2}\right)$ nanoparticles due to the high energy gap (Fig. 2). $\mathrm{PbO}_{2}$ particles not only absorb UV light, but also scatter visible light. The $\mathrm{PbO}_{2}$ nanoparticles at lower concentrations are aggregated as a clusters. When the concentration increases, the $\mathrm{PbO}_{2}$ nanoparticles form

ISSN 2071-0194. Ukr. J. Phys. 2019. Vol. 64, No. 2 
a network of paths in the (CMC-PVP) blend, as shown in Fig. 3. It is observed that the band gap decreases (Fig. 4) due to the blending with $\mathrm{PbO}_{2}$ particles [10].

Figure 5 represents the extinction coefficient of $\left(\mathrm{CMC}-\mathrm{PVP}-\mathrm{PbO}_{2}\right)$ nanocomposites as a function of the photon wavelength. The extinction coefficient indicates the amount of absorption loss when electromagnetic wave propagates through a material, which is a measure of the fraction of light lost owing to the scattering and absorption per unit distance of a penetration medium. The extinction coefficient is directly related to the absorption of a material and to the absorption coefficient. From Figure 5, the exponential decrease in the extinction coefficient with an increase in the photon energy represents that the fraction of light lost owing to the scattering and absorbance increases. In addition, the loss factor decreases, as the photon energy increases [11]. Figure 6 shows the relationship between the refractive index of $\left(\mathrm{CMC}-\mathrm{PVP}-\mathrm{PbO}_{2}\right.$ ) nanocomposites and the wavelength. It can be observed that the refractive index of an as-synthesized material decreases, as the photon energy increases. This reflects that the synthesized polymeric samples represent the normal dispersion behavior. The variation in $n$ values with the photon energy shows that the interaction between a photon and electrons takes place. Thus, one can get the desired material for fabricating the optoelectronics devices, by estimating the photon energy, as the internal energy of a device depends on the photon energy. The decrease in the extinction coefficient and refractive index with an increase in the photon energy may be correlated with an increase in the absorption coefficient and a decrease in the transmittance [11]. The complex dielectric constant is the basic intrinsic property of materials. The real part of the dielectric constant represents how much it will slow down the velocity of light in the material, whereas, the imaginary part of the dielectric constant indicates how a dielectric material absorbs the energy from an electric field owing to the dipole motion.

Figure 7 shows the real dielectric constant of $\left(\mathrm{CMC}-\mathrm{PVP}-\mathrm{PbO}_{2}\right)$ nanocomposites as a function of the photon energy, while Figure 8 displays the imaginary dielectric constant as a function of the photon energy. Figures 7 and 8 show that the real and imaginary parts of the dielectric constant de-

ISSN 2071-0194. Ukr. J. Phys. 2019. Vol. 64, No. 2

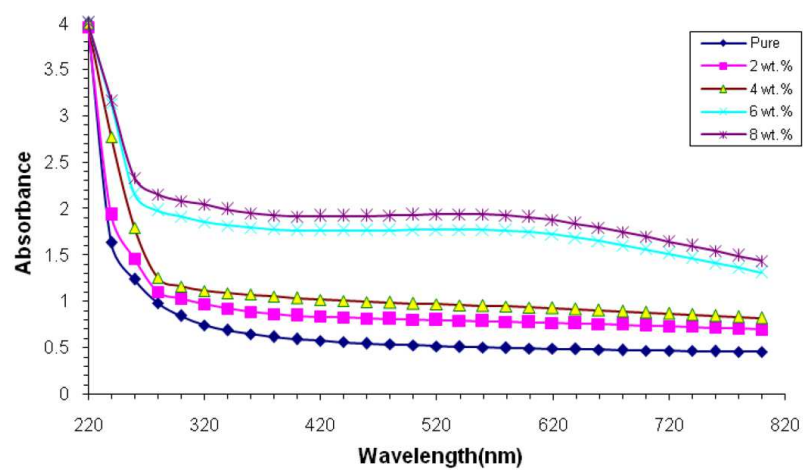

Fig. 1. Variation optical absorbance spectra of (CMC-PVP$\left.\mathrm{PbO}_{2}\right)$ nanocomposites with the photon wavelength

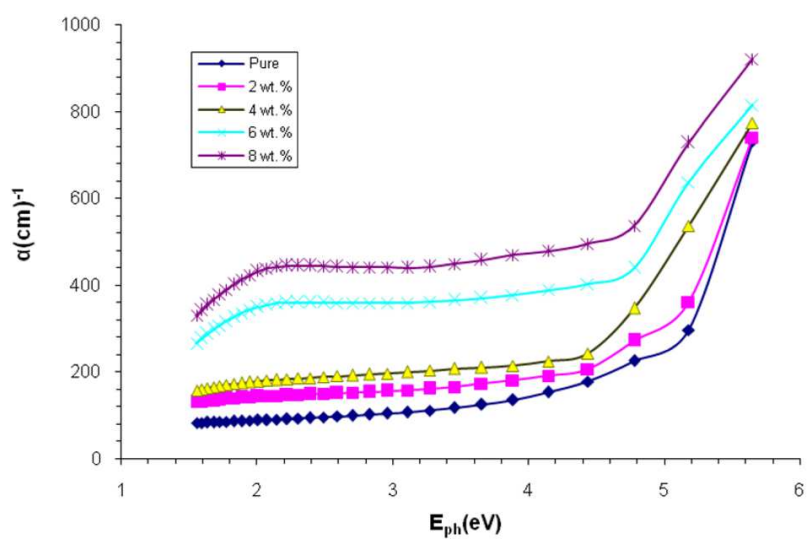

Fig. 2. Variation of the absorption coefficient of (CMC-PVP$\mathrm{PbO}_{2}$ ) nanocomposites with the photon energy

crease with an increase in the photon energy. The data on the real and imaginary parts of the dielectric constant provide knowledge concerning the loss factor, which is the ratio between the imaginary and real parts of the dielectric constant. These results indicate that, in the synthesized material, the loss factor increases with a decrease in the photon energy. The real part of the dielectric constant decreases a little-bit rapidly with an increase in the photon energy in the higher energy region but it decreases gradually in the lower one. However, the imaginary part of the dielectric constant decreases gradually with an increase in the photon energy [11]. The optical conductivity is one of the powerful tools for studying the electronic states in materials. The plot of the optical conductivity of ( $\left.\mathrm{CMC}-\mathrm{PVP}-\mathrm{PbO}_{2}\right)$ nanocomposites versus the photon energy is depicted in Fig. 9. The spectrum indicates that the optical 

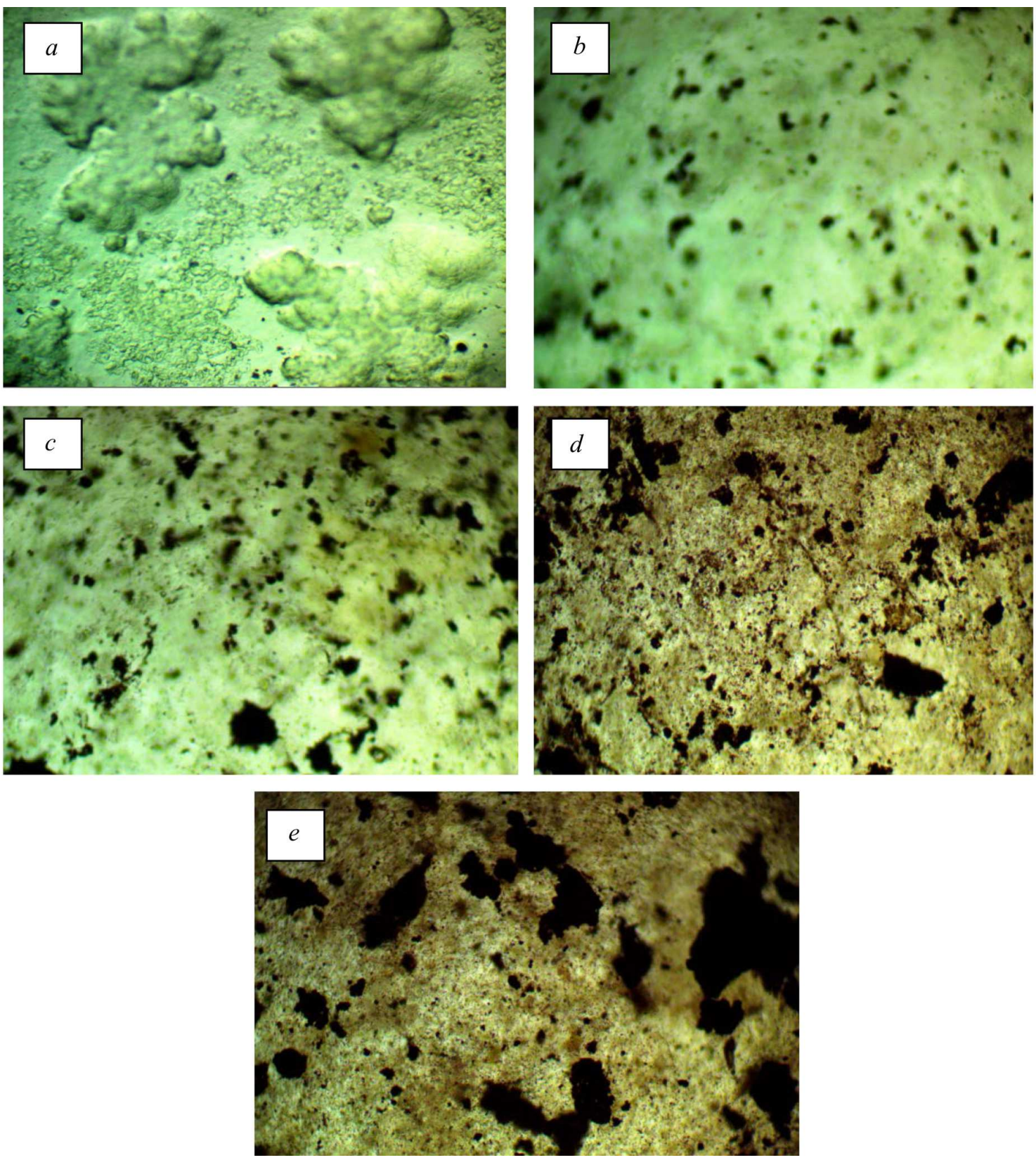

Fig. 3. Photomicrographs $(\times 10)$ of $\left(\mathrm{CVC}-\mathrm{PVP}-\mathrm{PbO}_{2}\right)$ nanocomposites: for pure one $(a), 2 \mathrm{wt} \% \mathrm{PbO}_{2}$ nanoparticles (b), 4 wt.\% (c), 6 wt.\% (d), 8 wt.\% (e)

conductivity increases with the photon energy. Due to a decrease in the direct band gap due to the addition of the dopant, the optical conductivity increases. It is very clear from the graph that the optical conductivity increases with the doping of material [12].
Figure 10 shows the variation of $\left(N / N_{0}\right)$ for $(\mathrm{CMC}-$ $\left.\mathrm{PVP}-\mathrm{PbO}_{2}\right)$ nanocomposites with different concentrations of $\mathrm{PbO}_{2}$ nanoparticles for a source (Cs-137, $5 \mu \mathrm{Ci}$ ) of gamma ray. The transmitted radiation decreases with an increase in the concentration of $\mathrm{PbO}_{2}$ nanoparticles, which is attributed to an increase in 


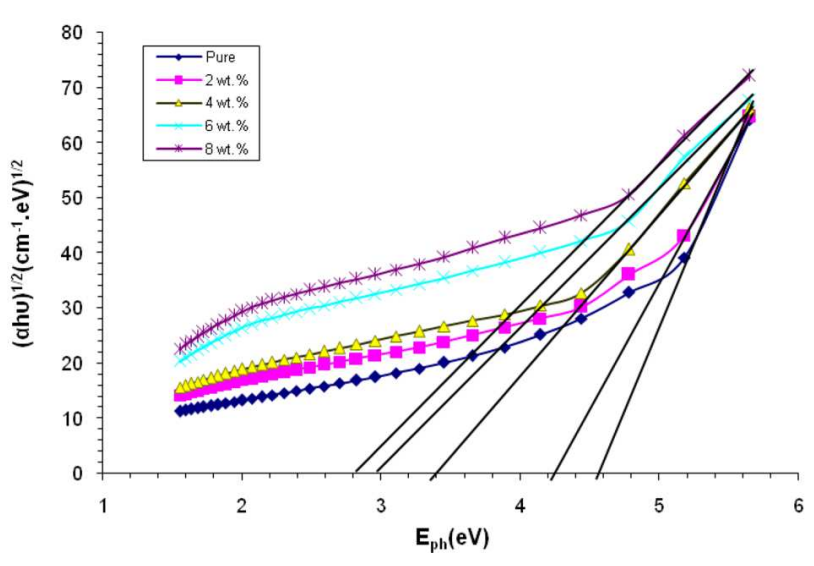

Fig. 4. Variation of $(\alpha h v)^{1 / 2}$ for $\left(\mathrm{CMC}-\mathrm{PVP}-\mathrm{PbO}_{2}\right)$ nanocomposites with the photon energy

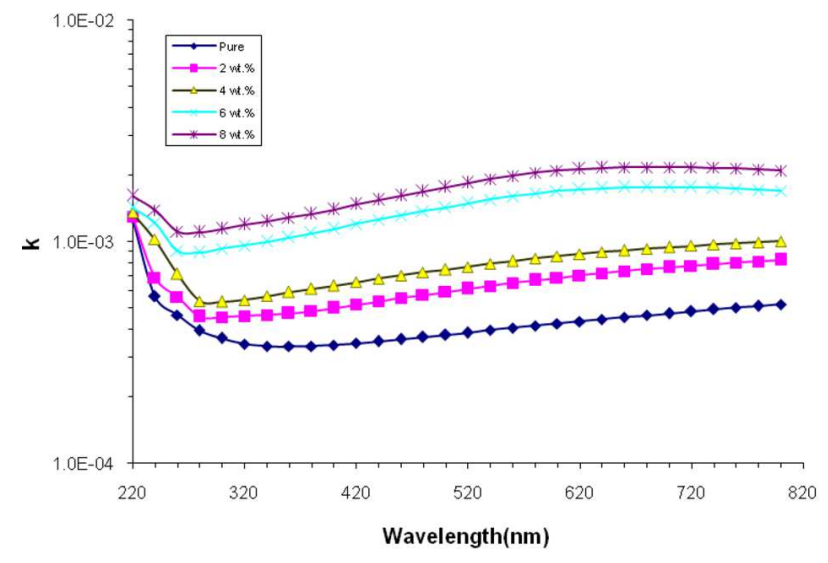

Fig. 5. Variation of the extinction coefficient for (CMC-PVP$\mathrm{PbO}_{2}$ ) nanocomposites with the wavelength

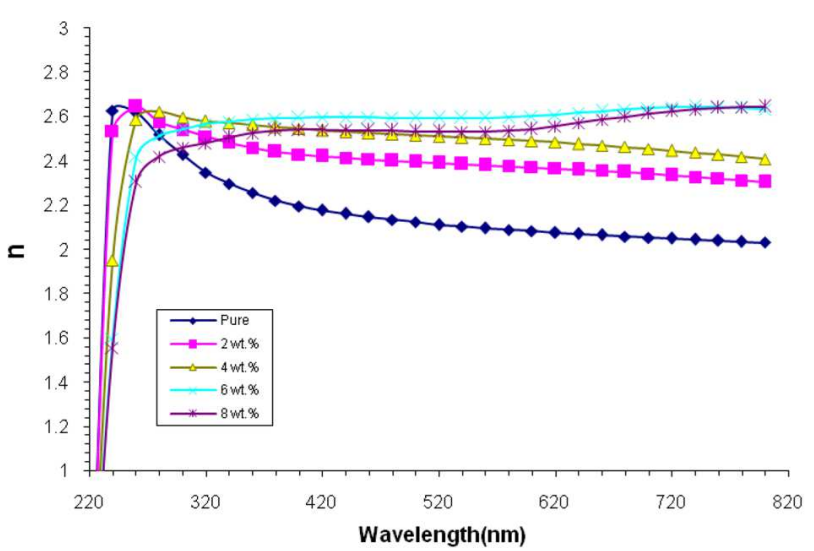

Fig. 6. Variation of the refractive index for (CMC-PVP$\mathrm{PbO}_{2}$ ) nanocomposites with the wavelength

ISSN 2071-0194. Ukr. J. Phys. 2019. Vol. 64, No. 2

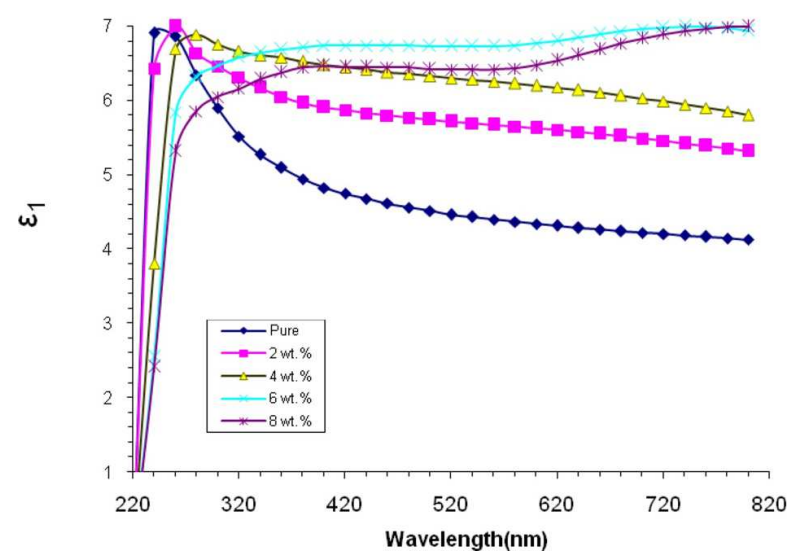

Fig. 7. Variation of the real part of the dielectric constant for $\left(\mathrm{CMC}-\mathrm{PVP}-\mathrm{PbO}_{2}\right)$ nanocomposites with the wavelength

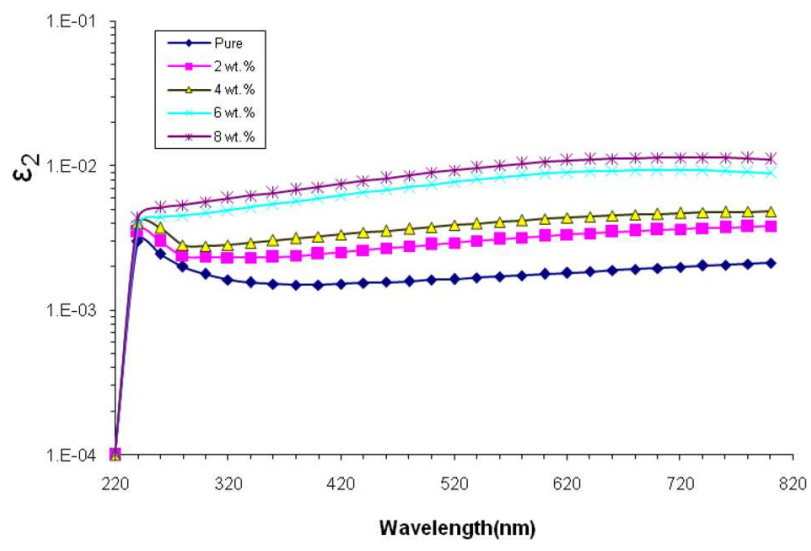

Fig. 8. Variation of the imaginary part of the dielectric constant for (CMC-PVP- $\mathrm{PbO}_{2}$ ) nanocomposites with the wavelength

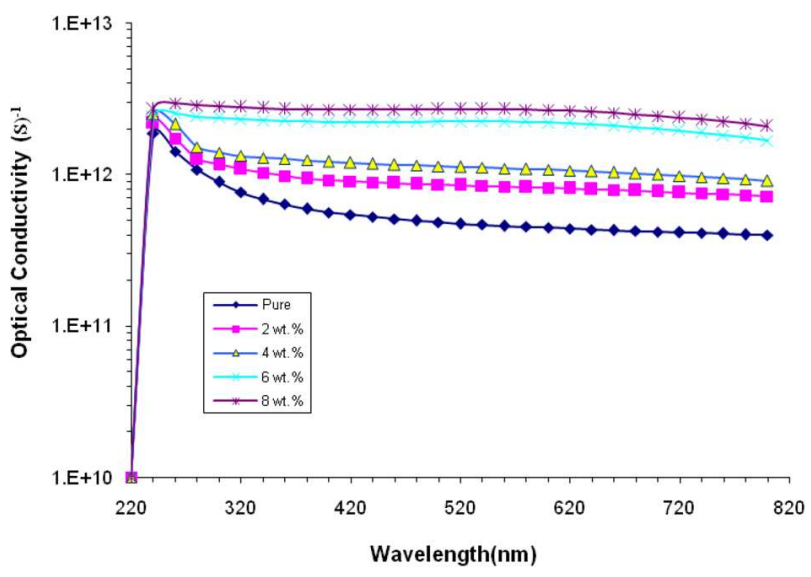

Fig. 9. Variation of the optical conductivity for (CMC-PVP$\mathrm{PbO}_{2}$ ) nanocomposites with the wavelength 


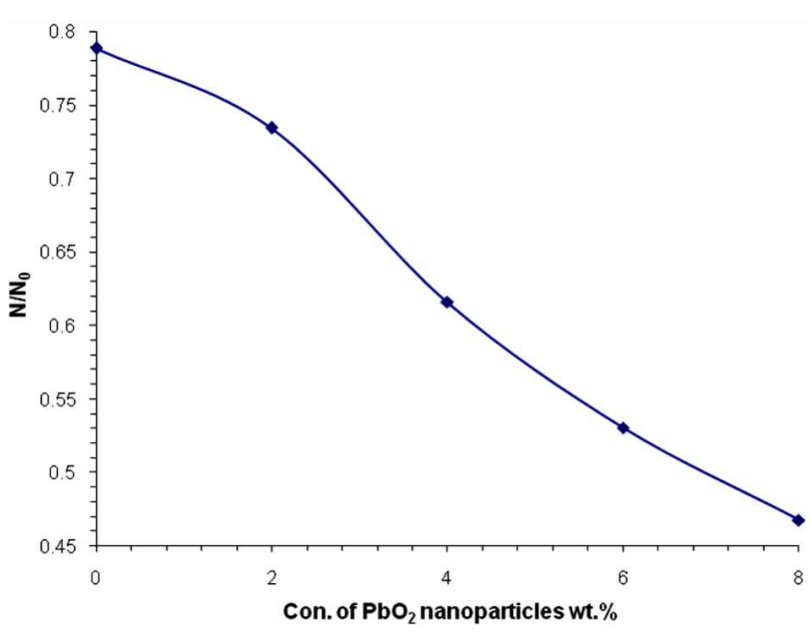

Fig. 10. Variation of $\left(N / N_{0}\right)$ for $\left(\mathrm{CMC}-\mathrm{PVP}-\mathrm{PbO}_{2}\right)$ nanocomposites with different concentrations of $\mathrm{PbO}_{2}$ nanoparticles for a source (Cs-137, $5 \mu \mathrm{Ci})$

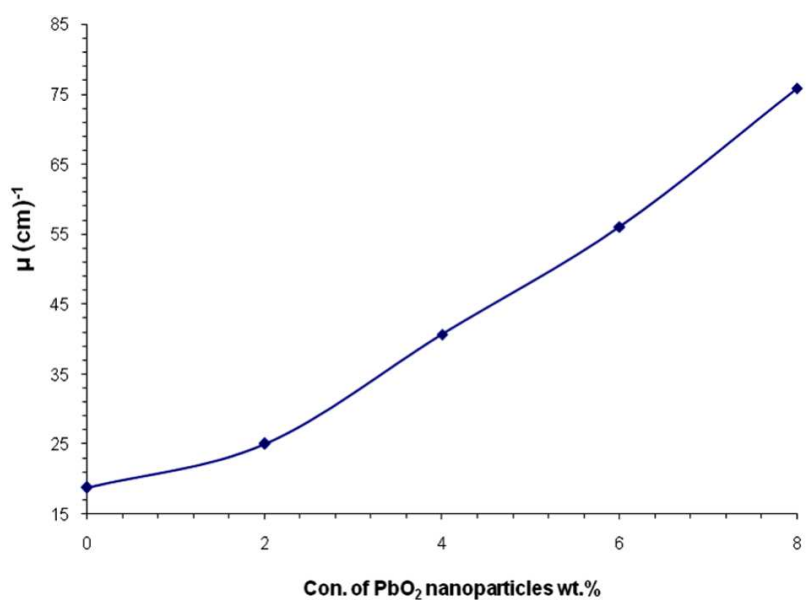

Fig. 11. Variation of the attenuation coefficients of gamma radiation for $\left(\mathrm{CMC}-\mathrm{PVP}-\mathrm{PbO}_{2}\right)$ nanocomposites as a function of the concentration of $\mathrm{PbO}_{2}$ nanoparticles

the attenuated radiation. Figure 11 shows the variation of the attenuation coefficient of gamma radiation for $\left(\mathrm{CMC}-\mathrm{PVP}-\mathrm{PbO}_{2}\right)$ nanocomposites as a function of the concentration of $\mathrm{PbO}_{2}$ nanoparticles. The attenuation coefficient increases with the concentration of nanoparticles, which is due to the absorption or reflection of gamma radiation by the nanocomposite shielding material. By comparing the results with those for concrete, we see very close results. However, the (CMC-PVP- $\mathrm{PbO}_{2}$ ) nanocomposites have an advantage over concrete because of their mobility and other electrical properties. They produce no magnetic or electrical field influencing the human health of users and/or patients $[13,14]$.

\section{Conclusions}

The optical absorbance of the (CMC-PVP) blend increases with the concentration of $\mathrm{PbO}_{2}$ nanoparticles. The (CMC-PVP-PbO 2$)$ nanocomposites have a high absorbance in the UV-region. The energy band gap of the (CMC-PVP) blend decreases with an increase of the concentration of $\mathrm{PbO}_{2}$ nanoparticles. The absorption coefficient, refractive index, extinction coefficient, real and imaginary parts of the dielectric constant, and optical conductivity of the (CMC-PVP) blend increase with the concentration of $\mathrm{PbO}_{2}$ nanoparticles. The (CMC-PVP- $\left.\mathrm{PbO}_{2}\right)$ nanocomposites have high attenuation coefficients for a source (Cs-137, $5 \mu \mathrm{Ci}$ ) of gamma radiation.

1. M. Aminian, M. Bakhshandeh, M. Allahbakhshian-Farsani, E. Bakhshandeh, N. Shakeri. Comparison of the protection performance in a composite shield and a lead standard shield in terms of biological effects in nuclear medicine. Iran J. Nucl. Med. 25, No. 2, 129 (2017).

2. E. Al-Sarraya, I. Akkurt, K. Günoglu, A. Evcinc, N.Ç. Bezir. Radiation shielding properties of some composite panel. Acta Physica Polonica A 132, No. 3, 490 (2017).

3. O. Gurler, U. Akar Tarim. Determination of radiation shielding properties of some polymer and plastic materials against gamma-rays. Acta Physica Polonica A 130, No. 1, 236 (2016).

4. A. Hashim, A. Hadi. Synthesis and characterization of novel piezoelectric and energy storage nanocomposites: biodegradable materials-magnesium oxide nanoparticles. Ukr. J. Phys. 62, No. 12, 1050 (2017).

5. I.R. Agool, K.J. Kadhim, A. Hashim. Preparation of (polyvinyl alcohol-polyethylene glycol-polyvinyl pyrrolidinonetitanium oxide nanoparticles) nanocomposites: Electrical properties for energy storage and release. Int. J. Plast. Tech. 20, No. 1, 121 (2016).

6. I.R. Agool, K.J. Kadhim, A. Hashim. Fabrication of new nanocomposites: (PVA-PEG-PVP) blend-zirconium oxide nanoparticles) for humidity sensors. Int. J. Plast. Tech. 21, No. 2, 397 (2017).

7. A. Hadi, A. Hashim. Development of a new humidity sensor based on (carboxymethyl cellulose-starch) blend with copper oxide nanoparticles. Ukr. J. Phys. 62, No. 12, 1044 (2017).

8. V. Sangawar, M. Golchha. Evolution of the optical properties of polystyrene thin films filled with zinc oxide nanoparticles. Int. J. Sci. \& Eng. Res. 4, No. 6, 2700 (2013).

ISSN 2071-0194. Ukr. J. Phys. 2019. Vol. 64, No. 2 
9. A.F. Mansour, A.Elfalaky, F. Abdel Maged. Synthesis, characterization and optical properties of PANI/PVA blends. IOSR J. Appl. Phys. 7, No. 4, 37 (2015).

10. E.J. James, Sh. Mishra, J. Jose, A.K. Patel, K. Das. Preparation and optical studies on zinc oxide: Poly vinyl alcohol (PVA) composite. Int. J. Sci. Res. Development 4, No. 1, 1042 (2016).

11. N.S. Wadatkar, S.A. Waghuley. Complex optical studies on conducting polyindole as-synthesized through chemical route. Egypt. J. Basic Appl. Sci. 2, 19 (2015).

12. P. Guggilla, A. Chilvery, R. Powell. Reducing the bandgap energy via doping process in lead-free thin film nanocomposites. Res. \& Rev.: J. Mater. Sci. 5, No. 1, 34 (2017).

13. I.R. Agool, K.J. Kadhim, A. Hashim. Synthesis of (PVAPEG-PVP- $\mathrm{ZrO}_{2}$ ) nanocomposites for Energy release and gamma shielding applications. Int. J. Plast. Tech. 21, No. 2, 444 (2017).

14. A. Hashim, A. Hadi. Novel lead oxide polymer nanocomposites for nuclear radiation shielding applications. Ukr. J. Phys. 62, No. 11, 978 (2017).

Received 26.02.18
А. Хашим, Х.Х.Х.Ал-Атmъл, С.Ф. Обейд

ВИРОБНИЦТВО НОВИХ ДЕШЕВИХ

НАНОКОМПОЗИТІВ (СУМІШ БІОПОЛІМЕРІВ

I НАНОЧАСТИНОК ОКИСУ СВИНЦЮ) ДЛЯ ЗАХИСТУ

ВІД ЯДЕРНОГО ВИПРОМІНЮВАННЯ:

ЇХ СТРУКТУРНІ І ОПТИЧНІ ВЛАСТИВОСТІ

Р е з ю м е

Дешеві полімерні нанокомпозити, призначені для захисту від ядерного випромінювання, володіють високолінійними коефіцієнтами поглинання, мають малу вагу і хороші механічні, оптичні та діелектричні властивості. Ми виготовили суміш полімерів карбоксиметил целюлози (CMC) і полівініл пірролідону (PVP) в концентраціях: 60 ваг.\% CMC і 40 ваг.\% PVP. У суміш додані наночастинки оксиду свинцю в різних концентраціях: $0,2,4,6$, та 8 ваг.\%. Вивчено структурні і оптичні властивості нанокомпозитів (CMC$\mathrm{PVP}-\mathrm{PbO}_{2}$ ). Показано, що поглинання сумішшю (CMCPVP) і оптичні константи ростуть і ширина забороненої зони зменшується із зростанням концентрації наночастинок $\mathrm{PbO}_{2}$. Нанокомпозити $\left(\mathrm{CMC}-\mathrm{PVP}-\mathrm{PbO}_{2}\right)$ мають високолінійні коефіцієнти поглинання гамма-випромінювання. 